\title{
MOŽNOSTI PODPORY VENKOVSKÉHO CESTOVNÍHO RUCHU V OBLASTI MORAVSKOSLEZSKÉ BESKYDY
}

\author{
Klára Václavínková
}

\section{Klíčová slova:}

agrotourism, cestovní ruch, podpora

\section{Key words:}

agrotourism, tourism, support

\begin{abstract}
Abstrakt
Cílem článku je určení, které prírodní, kulturní a sportovní atraktivity v Moravskoslezských Beskydech lze využít pro podporu venkovského cestovního ruchu. V první části jsou vymezeny stěžejní pojmy ve venkovském cestovním ruchu jako je agrotourism nebo udržitelný rozvoj, následuje zhodnocení přírodních a kulturních předpokladů v oblasti. V závěru jsou uvedeny jednotlivé možnosti pro podporu venkovského cestovního ruchu. Mezi základní předpoklady pak patří přírodní a kulturní atraktivity v oblasti a jejich využití pro podporu podnikání ve venkovském cestovním ruchu.
\end{abstract}

\begin{abstract}
This article aims to identify specific requirements for the development of rural tourism in the area known as the. In the first part of the core concepts are defined in the rural tourism as Agrotourism or sustainable development, followed by assessment of natural and cultural assumptions in the area. In conclusion the options for development. The basic assumptions include the natural and cultural attractions in the area and their use for business support in rural tourism.

\section{Úvod}

Venkovský cestovní ruch a jedna $\mathrm{z}$ jeho forem agrotourism patří mezi nové a dynamicky se rozvíjející oblasti v cestovním ruchu. Tato oblast dává možnost rozvoji nabídky pro specifický druh klientely, jako jsou rekreační služby pro seniory nebo mládež a další specifické skupiny. Charakter venkovského cestovního ruchu je dán decentralizovaným ubytováním s nízkou kapacitou, nabízí se téměř rodinné zázemí a individuální prrístup k potřebám zákazníka. Venkovský cestovní ruch je možností, jak strávit zdravou dovolenou v přírodě a ve společnosti svých blízkých. Vychází z myšlenky udržitelného rozvoje, který si klade za cíl ochranu prrírody.
\end{abstract}

\section{1. Úvod do problematiky}

Služba je jakákoliv aktivita nebo výhoda, kterou jedna strana může nabídnout druhé straně, je v zásadě nehmotná a jejím výsledkem není vlastnictví. Produkce služby může, ale nemusí být spojena s hmotným produktem [6, s.710].

Služby cestovního ruchu lze rozdělit na několik kategorií. Jsou to služby hlavní představující nezbytné činnosti jako doprava, stravování, služby vedlejší, kde patří průvodce, tlumočník, tvorba programu pro volný čas. Další skupinou jsou služby doplňkové jako informatika, propagace a reklama, a poslední služby infrastrukturní zahrnující dopravní sít', obchodní sít a nebo také systém zdravotní péče[3]. 
Mezi specifické vlastnosti služeb patří nehmotnost, neoddělitelnost od osoby poskytovatele, proměnlivost, pomíjivost a absenci vlastnictví, která znamená, že službu nelze vlastnit[3].

Nehmotnost služeb znamená, že služby nelze jednoduše vystavit, ani je před zakoupením prohlédnout, ochutnat, poslechnout či se jich dotknout. Zákazník může před nákupem podrobně prozkoumat barvu, funkce a výkon hi-fi sestavy, kterou si chce koupit. Pokud však kupuje účes, nemůže si předem prohlédnout výsledek [6, s.714].

Neoddělitelnost od osoby poskytovatele popisuje interakci mezi poskytovatelem služby a zákazníkem [ 3, s.71].

Proměnlivost služeb znamená, že kvalita služeb závisí na tom, kým jsou poskytovány, a také na tom, kdy, kde a jak jsou poskytovány. Kvalitu služeb jako takovou lze jen obtížně řídit. Některé hotely si např́iklad získaly pověst, že poskytuji lepši služby než ostatní [6, s.716].

Venkovský cestovní ruch patří společně s agrotourism do skupiny udržitelný cestovní ruch. Cílem je návrat k př́rodě a enviromentální počínání. Do venkovského cestovního ruchu patří agroturistika, vesnická turistika, ekoagroturistika a chataření, chalupaření[5, p.54].

Venkovská turistika je druh cestovního ruchu, jehož aktivity jsou bezprostředně spjaty s př́rodou, krajinou a venkovským prostředím. Někdy je známá pod názvem "zelená turistika". Představuje soubor prrírodních a kulturních atraktivit: sport, kulturu, řemesla, školy v přírodě, ubytovací zařízení převážně nižších kategorií a další speciální nabídku služeb. Její zvláštnost spočívá v decentralizaci ubytovacích zařízení, což umožňuje rozmělnit četnost turistů, a tak eliminovat negativní dopady, které s sebou nese "organizovaná turistika" (tzv. masová turistika - ohromné soustředění lidí v turistických centrech, devastace krajiny po dobu turistické sezony ap.) [9].

Udržitelný cestovní ruch je cestovní ruch, který dlouhodobě nenarušuje přírodní, kulturní a sociální prostředí [12, s.302].

Udržitelný rozvoj lze charakterizovat jako takový rozvoj, který zabezpečuje uspokojení současných potřeb, aniž by ohrozil možnosti uspokojení potřeb generací budoucích. Udržitelný rozvoj turistiky má vést $\mathrm{k}$ řízení všech zdrojů, a to tak, aby byly uspokojeny ekonomické, sociální a estetické potřeby při zachování kulturní integrity, nejdůležitějších ekologických procesů, biologické různorodosti a procesů, které umožňují život. Produkty udržitelné turistiky jsou produkty, které fungují v souladu s místním životním prostředím, společností a kulturou tak, aby z nich životní prostředí, společnost a kultura měly užitek, a aby se nestaly obětí rozvoje turistiky [12, s.302].

Agrotourism je druh cestovního ruchu, který je prezentován turistickými nebo rekreačními pobyty na venkově na rodinných farmách, jejichž hlavní náplní je poznávání alternativního způsobu života v blízkém kontaktu s prŕírodou [12, s.14].

Agrotourism je také doplňková činnost hlavní zemědělské výroby může být doplňkovým zdrojem příjmů farmy nebo zemědělského podniku, přináší existenční jistotu, výrazně finalizuje produkci podnikatelských subjektů tím, že výhodněji mohou zpeněžit vlastní výrobky, ubytovací kapacity, dokonce i technologický proces a prostředí farmy, hospodářského domu, pole, louky i krajinu, vytváří podmínky pro hospodaření i na méně výnosných či dokonce ohrožených zemědělských farmách a podnicích, vytváří dodatečný 
odbyt zemědělských výrobků a je stimulem pro rozširrení výroby. Provozování agroturistiky vyžaduje určitý stupeň vybavenosti zemědělské usedlosti a tím se zvyšuje celkový standard zemědělských domácností [9].

\section{Metodika a cíl výzkumu}

Hlavním cílem příspěvku je vymezit, které přírodní, kulturní a sportovní atraktivity v Moravskoslezském kraji lze využít pro podporu venkovského cestovního ruchu, potažmo v oblasti Moravskoslezských Beskyd. Dílčím cílem je pak vyspecifikovat konkrétní atraktivity a jejich využití pro tvorbu doplňujících aktivit pro venkovský cestovní ruch.

Metodika nám udává pracovní postup této práce. Bylo pracováno s dostupnými informacemi jak z odborné literatury, tak z dostupných elektronických zdrojů a autorova vlastního pozorování. Autor vychází z metod empirických, přímo popisuje realitu. Informace byly mezi sebou porovnány a výsledkem je pak přehled atraktivit, které lze využít jako formu podpory venkovského cestovního ruchu v Moravskoslezských Beskydech.

Metoda pozorování byla provedena v období listopad 2010 až květen 2011. Vlastní provedení metody pak využívalo přímo návštěvu daného zařízení, telefonický rozhovor nebo zisk informací studiem elektronických zdrojů. Způsob se odvíjel dle možností autora a ochoty komunikovat $\mathrm{v}$ zařízeních. Hlavním cílem této metody bylo určit, která zařízení působící v Moravskoslezském kraji jsou zaměřena na venkovský cestovní ruchu. Zařízení byla vybrána dle kriterií uvedených v kapitole 3.1. Hlavní výzkumnou otázkou bylo určit počet zařízení věnujících se venkovskému cestovnímu ruchu v oblasti Moravskoslezského kraje. Další výzkumnou otázkou je pak určení aktivit, které jsou přímo využitelné jako podpora pro rozvoj venkovského cestovního ruchu v dané oblasti.

\section{Oblast Moravskoslezských Beskyd}

Následující kapitola popisuje oblast Moravskoslezských Beskyd. Území Moravskoslezských Beskyd se rozprostírá ve východní části České Republiky a lemuje se podél slovenské hranice. Rozkládá se na území okresů Frýdek - Místek, Nový Jičín, nebo kolem měst Valašské Meziř́ičí a Rožnov pod Radhoštěm, které jsou součástí okresu Vsetín. I když je oblast převážně řídce osídlena, celkový počet obyvatel těchto krajů převyšuje 400000 obyvatel na základě údajů Českého statického úřadu z let 2010.

\subsection{Předpoklady pro rozvoj venkovského cestovního ruchu}

Pro naplnění cíle článku bylo nutné zmapovat zařízení, které se věnují venkovskému cestovnímu ruchu. V současnosti však neexistuje kompletní přehled všech podnikatelů ve venkovském cestovním ruchu. K dispozici jsou pouze údaje Sdružení podnikatelů v agroturistice ČR, nevládní nadace ECEAT ČR a Turistické informační kanceláře Dovolená na chatě. Podnikatelů však bude podstatně více, jelikož někteří nejsou členy výše zmíněných organizací. V mnohém jsou tyto farmy zastoupeny jízdárnami, kde je provozována hipoturistika apod. Následuje stručný přehled v současnosti fungujících agrofarem v Moravskoslezském kraji.

Byly vybrány farmy, které svou kapacitou i vybavením poskytují dostatečnou kapacitu a kvalitu pro zákazníka. Informace byly získány studiem elektronických zdrojů a vlastním pozorováním autora. Informace jsou platné k lednu 2011.

Hlavní kriteria pro výběr farem byla :

- Kapacita zařízení - zde byly vybírány zařízení, které svou kapacitou nepřekračuji 30 osob. 
- Nabídka doprovodných aktivit musela obsahovat tři a více doprovodných programů vhodných pro agroturistiku.

- Zařízení má nabídku služeb jako doplňující činnost zemědělské výroby.

- Byly zde zahrnuty i jízdárny, které odpovídají alespoň jednomu z kritérií.

Těmto podmínkám vyhověli tyto farmy:

- Opavsko - Krnovsko: Ranč u Kulhavé Sovy a Ranč Solný potok

- Jeseníky: Agroturistika Ljuba Kielarová, Ekofarma Babočka, Farma Bovine, Hamř́rkova stáj a Ranch N.

- Poodř́i: Agroturistika U Haitlů.

- Beskydy - Valašsko: Zemědělská usedlost Bludička a Ubytování Valašské chalupy.

- Ostravsko: V Ostravě ani jejím blízkém okolí se momentálně nenachází, vzhledem k přírodním podmínkám, žádné zařízení zaměřené výhradně na agroturistiku.

Chráněná krajinná oblast Beskydy byla zřízena v roce 1973. Má za úkol chránit přírodu a krajinu Moravskoslezských Beskyd, Vsetínských vrchů a Javorníků. Díky rozloze 1200 km² je naší největší chráněnou krajinnou oblasti v republice. Je jediným územím v České republice, kde žijí zároveň medvědi, vlci i rysi a kde se vyskytují zachovalé zbytky původních karpatských lesů. Později valašská a pasekářská kolonizace způsobila v horách známý krajinný ráz, který je typický pro celé Západní Karpaty, a to jsou louky, pastviny s orchidejemi a jalovci, políčka a meze vysoko v horách. Celé území Beskyd je také zařazeno v Evropských významných lokalitách a jsou zde dvě Ptačí oblasti. Proto je tedy oblast součástí soustavy evropských chráněných území Natura 2000 [13].

Nejcennější lokality chráněné krajinné oblasti jsou chráněny jako národní př́rodní rezervace, které mají nad sebou tu nejpřísnější ochranu, dále přírodní rezervace a přírodní památky. Na území chráněné krajinné oblasti Beskydy bylo v roce 2011 vyhlášeno padesát chráněných lokalit, z čehož zhruba 3/4 náleží Moravskoslezským Beskydám. Tato takzvaná maloplošná zvláště chráněná území jsou v terénu značena tabulí se státním znakem a hranice tohoto území jsou vymezeny dvěma červenými pruhy na stromech. Mezi čtyřicet zvláště chráněných lokalit v Moravskoslezských Beskydech patří prrírodní rezervace Čerňavina, Velký polom, Travný, Travný potok, Malenovický kotel, Mazácký Grúnik, Zimný potok, Poledňana, Draplavý, Bučací potok, Smrk, Malý Smrk, Studenčany, V Podolankách, Klíny, Nořičí, Huštýn, Trojačka; př́rodní památky Motyčanka, Kyčmol, Byčinec, Obidová, Vodopády Satiny, Pod Lukšincem, Ondrášovy díry, Podgrúň, Kněhyňská jeskyně, Velký kámen, Zubří, Rákosina ve Stříteži, Poskla, Pod Juráškou, Kudlačena, Kladnatá - Grapy, Lišková; národní přírodní rezervace Mionší, Mazák, Kněhyně, Radhošt’ a Salajka [14, 15, 16].

\subsection{Popis jednotlivých přírodních památek}

Pro kompletní představu o jedinečnosti rázu beskydské krajiny následuje popis jednotlivých přírodních památek. Popis jednotlivých památek př́ímo ukazuje, co mohou jednotliví provozovatelé nabídnout svým hostům. Na uvedené lokality lze realizovat výlety a využít jejich možnost, jako součást propagace daného zařízení.

NPR Mionší patří $\mathrm{k}$ nejznámějším rezervacím $\mathrm{v}$ Moravskoslezských Beskydech a svou rozlohou $\mathrm{k}$ největším pralesủm $\mathrm{v}$ České republice. První územní ochrana pralesa Mionší se datuje již od roku 1922. Cílem je ochrana zbytků jedlobukového karpatského pralesa s javorem klenem a smrkem v Moravskoslezských Beskydech s mozaikou drobných zbytků lesních luk a pastvin (polan), pramenisky a skalkami, s bohatou faunou a flórou. V minulosti bylo možné navštívit prales Mionší s průvodcem po zřízené naučné stezce. Těmito 
návštěvami však prales značně utrpěl, a tak od 1. ledna 1989 byla tato stezka z důvodu zachování nerušeného přírodního prostředí pro rozmnožování a úkryt řady vzácných druhů živočichů pro veřejnost uzavřena. Vstup do NPR Mionší je i nadále přísně zakázán [19].

PR Travný se rozkládá na západním svahu hory Travný od vrcholu až po úpatí k toku říčky Mohelnice. Chrání se zde fragmenty prrirozených porostů pralesovitého charakteru $\mathrm{v}$ komplexu bučin $\mathrm{v}$ širokém rozpětí vegetačních stupňů od montánní olšiny po zakrslou bukovou smrčinu [20].

PP Vodopády Satiny představuje unikátní část toku říčky Satiny. Jedná se o přibližně jeden km dlouhý úsek, který má místy charakter soutěsky o hloubce až 15 m, s několika vodopády, peřejemi, přehrádkami a dalšími zajímavými tvary. Nachází se v masivu Lysé hory v údolním zářezu Satiny. Chráněná je unikátní geomorfologická a geologická lokalita v rámci flyšových Karpat [21].

PP Pod Lukšincem tvoří horské květnaté louky, které se nacházejí ve spodní části severovýchodně orientovaných svahů Lukšince - jedné z rozsoch Lysé hory. Hlavním předmětem ochrany byla populace rostliny hořce bezlodyžného. Ten byl ale počátkem 80 . let 20. století vyhuben, nadále zůstává chráněna druhově bohatá květnatá horská louka s výskytem chráněných druhů rostlin [22].

PP Ondrášovy díry představuje jeskynní systém na rozeklaném temeni rozsochy Lukšince. Chrání se zde podzemní systém pseudokrasových puklinových a rozsedlinových jeskyní a jejich ekologických funkcí. Tato přírodní památka je ojedinělá zoologická lokalita s koloniemi ohrožených druhů netopýrů [23].

NPR Mazák jsou význačné beskydské jedlobukové pralesy a klimaxové smrčiny. Nachází se na prudkých západních svazích pod vrcholem Lysé hory. Předmětem ochrany je zachování porostů pralesovitého charakteru blízkých přirozené druhové skladbě. Ve vrcholové části je vylišený osmý lesní vegetační stupeň, který je v Moravskoslezských Beskydech velmi ojedinělí. Obdobná lokalita se v nachází pouze na vrcholu Smrku [24].

PR Bučací potok je část levostranného přítoku řeky Ostravice o celkové délce asi $1260 \mathrm{~m}$. Snaží se o uchování a ochranu výjimečného ekotopu Bučacího potoka, který je jedinečný svými kaskádami a existencí jednoho z největších vodopádů v moravské a slezské části Karpat, se zachovalými zbytky sut'ových lesů a výskytem chráněných a ohrožených druhů rostlin a živočichů patří mezi skvosty tohoto území [25].

PR Smrk tvoří vysokohorský smrkový les a smíšené porosty ve vrcholové a podhřebenové oblasti na prudkých jihovýchodních a severozápadních svazích izolovaného masívu Smrku. Cílem ochrany jsou zbytky přirozených smrkových bučin s příměsí jedle bělokoré a javoru klenu se zachovanými dynamickými procesy probíhajícími v přirozených ekosystémech. Střídají se různé typy přírodních stanovišt' od prameništ' po kamenité až balvanité sutě [26]

NPR Kněhyně zaujímá vrchol a přilehlý prudký svah Kněhyně a nehluboké sedlo oddělené masívem Čertova mlýna. Zájmem ochrany je jedinečný zbytek přirozených lesních porostů $\mathrm{s}$ bohatou škálou lesních typů $\mathrm{v}$ exponovaných polohách $\mathrm{s}$ typickou faunou, flórou a pseudokrasovými jevy [27].

PP Kněhyňská jeskyně je rozsáhlý vertikální jeskynní systém, který se nachází na jihovýchodním svahu hory Kněhyně v Radhošt'ské hornatině v Moravskoslezských Beskydech. Předmětem ochrany je zachování jedinečného fenoménu pískovcového pseudokrasu v centrální oblasti výskytu mocných godulských vrstev s nejhlubší pseudokrasovou propastí v České republice [28].

NPR Radhošt' je představována velmi prudkým podhřebenovým severním svahem nejznámější beskydské hory Radhost', sahá až po rozsochu Mjaší v délce 2,8 km. Cílem ochrany je rozsáhlý komplex porostů vrcholových partií Radhoště, vystavený v hřebenových polohách severních a severovýchodních svahů nepříznivým klimatickým vlivům, zejména sněhu a námraze [29]. 
PP Zubří tvoří vlhká louka v zahradě u rekreačního domku č. p. 173 na severním okraji obce Zubří v údolí Zuberského potoka. Nachází se v Rožnovské brázdě v nadmořské výšce $395 \mathrm{~m}$. Tato louka je typická svou bohatou populací šafránu karpatského, je to jeden z mála dochovaných fragmentů původní lokality podél Zuberského potoka [30].

NPR Salajka je karpatský jedlobukový prales na severním svahu hraničního hřebene Moravskoslezských Beskyd $\mathrm{v}$ pramenné oblasti pravých přítoků Bílé. Jeden z nejzachovalejších a nejznámějších jedlobukových původních karpatských přirozených lesů v Beskydech s mimořádně silnými jedlemi, přes 60 let bez úmyslných těžebních zásahů.

Moravskoslezské Beskydy jsou místem pro návštěvníka jistě úchvatným a lákavým. Kulturní památky ve spojení s folklorními akcemi dokážou návštěvníka této lokality opravdu mile překvapit a společensky obohatit. Najdou se zde aktivity, které dokážou uspokojit kteroukoliv zájmovou skupinu, at' už jsou to aktivní lidé, nebo ti, kteří dají přednost odpočinku. Spokojený pobyt se zde dá nalézt ve třech základních komponentech. Příroda, kultura a dobrodružství [31].

Př́rodní památky oblasti Moravskoslezských Beskyd byly již podrobně popsány v kapitole 2.2. Dále následuje podrobný popis nové krajinné oblasti v Beskydech, která přibyla v roce 2011 a je to chráněná lokalita Lysá Hora.

PR Lysá hora představuje zbytky původních lesních porostů horských smrčin ve výškovém rozpětí 860 až 1315 m. Nachází se na východním úbočí Lysé hory (1323 m n. m.) v Lysohorské hornatině v Moravskoslezských Beskydech. Předmětem ochrany této rezervace jsou fragmenty původních porostů horských smrčin na východním úbočí Lysé hory a ochrana přirozených procesů, které umožňují existenci řady vzácných a ohrožených druhů rostlin i živočichů. Vyhlášením PR Lysá hora v roce 2011, včetně ochranného pásma jižně od vrcholu, došlo k integraci maloplošných zvláště chráněných území ve vrcholové části Lysé hory (NPR Mazák, PR Malenovický kotel a PR Lysá hora). Jako celek je tak účinně chráněn jedinečný fenomén nejvyššího vrcholu Moravskoslezských Beskyd. Rezervace je také součástí Ptačí oblasti Beskydy. Předmětem ochrany jsou populace čápa černého, jeřábka lesního, tetřeva hlušce, kulíška nejmenšího, puštíka bělavého, žluny šedé, datla černého, strakapouda bělohřbetého, datlíka tříprstého, lejska malého a jejich biotopy [32].

\subsection{Popis jednotlivých kulturních památek}

Mezi kulturní památky můžeme zařadit přírodní ale zároveň nejstarší kulturní důkaz o pobytu člověka. Je to jeskyně Šipka u Štramberku pocházející ze starší doby kamenné asi před 40000 lety. Jsou zde známky toho, že se tady usídlila skupina neandrtálců, u vchodu do jeskyně byla objevena dětská čelist a dále v jeskyni bronzové nástroje. V období gotiky vyrostly na území Moravskoslezských Beskyd četné hrady, z nichž nejvýznamnější jsou Hukvaldy, Starý Jičín, několik dochovaných zrrícenin Šostýn, Rožnov pod Radhoštěm nebo třeba zbytky hradu na Landeku. Mezi největší kulturní poklady patří velké množství vystavěných dřevěných kostelíků, jejichž většina patři k chráněným kulturním památkám s mnoha dřevěnými soškami, řezbami a obrazy známých umělců a další vzácné nástěnné malby. Jsou to například kaple svatého Cyrila a Metoděje Radhošt' v oblasti Trojanovic, Kostel sv. Petra a sv. Pavla v oblasti Albrechtic u Českého Těšína, kostel svatého Bedřicha v Bílé, kostel Panny Marie, pomocnice křest'anů v Gruňi, filiální kostel Božího Těla v Gutech a mnoho dalších. Další kulturní památky jsou zámečky (Žerotínský, Frýdecký), pomníky (partyzánského hnutí na Moravce, pomník padlých ve Frýdlantě nad Ostravicí), technické památky (telekomunikační věž na Lysé hoře, technické muzeum tatra Kopřivnice) a rozhledny (Prašivá, Bílá hora, Štramberská trúba) [33, 34].

Oblast Moravskoslezských Beskyd je oblastí s bohatou kulturní tradicí. V současné době ji připomínají folklórní festivaly, čerpající z umění řady souborů lidových písní a tanců, četné 
jarmarky a jiné zábavné doplňky těchto akcí. Jedním z nejvýznamnějších festivalů jsou folklorní slavnosti „Gorolski Święto“, jejichž věhlas sahá až za hranice České republiky. Tento festival je totiž festival mezinárodního typu a svou specifickou atmosférou a programem si našel své příznivce nejenom v celé České republice, Polsku, Slovensku, ale i v celé řadě zemi Evropy. Mezi další folklorní akce můžeme zařadit Lomňanské jarmarky, které se konají v obou těchto obcích, Slezské dny v Dolní lomné anebo také velice významné akce města Rožnova pod Radhoštěm, jehož valašský folklor je také velice populární. Díky Valašského muzea $\mathrm{v}$ prrírodě můžeme $\mathrm{v}$ Rožnově navštívit nespočet akci, které se odvíjejí podle roční doby a většinou se opakují každý rok. Je to každoroční masopust, Velikonoce na Valašsku, stavění máje, zvonečkový, nebo starodávný jarmark a samozřejmě nesmí chybět Valašské Vánoce společně s živým betlémem [33, 34].

\subsection{Zimní sporty}

Velké množství ski areálů se rozděluje do několika oblastí, mezi které se řadí oblast Bílá, Čeladná, Frýdek - Místek, Grůn̆, Javorový, Malenovice, Morávka, Ostravice, Pustevny a Těšínsko. Mezi největší a nejatraktivnější se řadí ski areál Bílá, který jako jediný z celých Moravskoslezských Beskyd má v provozu sedačkovou lanovku. Lyžařský areál $\mathrm{v}$ Bílé se nachází v údolí řeky Bílá Ostravice a je tvořen řadou sjezdových tratí od závodní sjezdovky s homologací FIS, přes sjezdovky střední obtížnosti, až po sjezdovky pro začátečníky a výuku dětí. Součástí areálu je snowpark pro snowboarding. Dalším velice atraktivním zimním střediskem, každoročně navštěvovaným velkým počtem návštěvníků je ski areál Mosty u Jablunkova. Toto zařízení je unikátní v celé České republice se zaměřením na celoroční volnočasové aktivity. V zimní sezoně nabízí 3 upravované sjezdovky o celkové délce $2100 \mathrm{~m}$, umělé zasněžování, intenzivní osvětlení sjezdových tratí, snowpark, lyžařskou školu, 44 km upravovaných běžeckých tratí, značkový ski servis, stanoviště horské služby a bobovou dráhu s celoročním provozem. Nejdelší sjezdovka, která je zároveň nejdelší zasněžovanou sjezdovkou v Beskydech, se nachází ve ski areálu Řeka a měří 1300 m.

Běžecké tratě se obvykle nacházejí v blízkosti samotných ski areálů, v oblastech Lysé hory, Ostravice, Čeladné a Moravky. Významnou je Lysohorská magistrála, která má tři trasy A, B, C. Nejdelší z nich je trasa $B$, která vede z Albínova náměstí Malenovickým kotlem na Ivančenu, dále na Labažky, Zimný a na vrchol Lysé hory a má délku 13 km [35].

\subsection{Demografické členění}

Obyvatelstvo chráněné krajinné oblasti Moravskoslezské Beskydy představuje pouze malou část počtu obyvatel všech okresů nacházejících se na území. Podíl obyvatel okresů Frýdek Místek, Nový Jičín a Vsetín je pouhých $7 \%$ pro celou oblast. Celkový počet obyvatel je 37108 obyvatel nerovnoměrně rozmístěných v jednotlivých okresech. Z grafu č. 1 je zřetelně vidět, že největší koncentrace obyvatel se nachází v okrese Vsetín, kde počet obyvatel 22851 představuje $16 \%$ z celého okresu a $61,5 \%$ z celého území chráněné krajinné oblasti. To je ve srovnání s ostatními okresy výrazný podíl. Takto vysoké procentu počtu obyvatel je dáno právě tím, že na území vsetínského okresu se nachází Rožnov pod Radhoštěm, který má jako jediný z celé chráněné krajinné oblasti Moravskoslezské Beskydy statut města. S celkovým počtem obyvatel 16871 je nejlidnatějším městem v celé oblasti a díky své výhodné poloze na hranicích mezi Moravskoslezskými Beskydy a Javorníky, je také centrem správy celé chráněné krajinné oblasti Beskydy [37]. 
Graf č.1: Geografické rozložení počtu obyvatel CHKO Moravskoslezské Beskydy

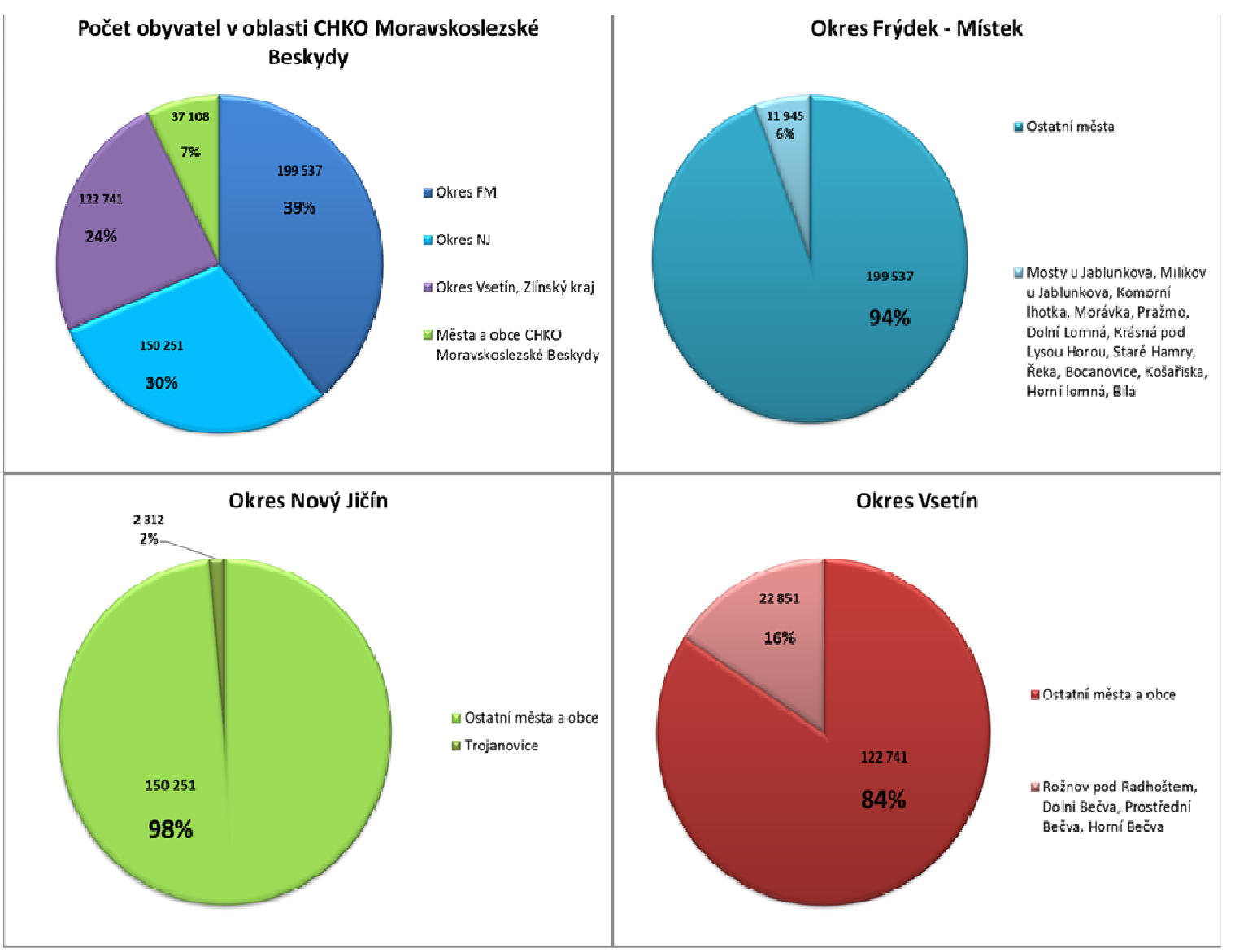

Zdroj: ČSÚ;2011, vlastní vyhodnocení

Na rozdíl od Vsetínského okresu, kde se nachází převážná většina počtu obyvatel, ale pouze 3 další obce, se v okrese Frýdek - Místek nachází největší počet obcí v oblasti. V tomto okrese se nachází 13 obcí situovaných převážně v údolích pohoří Moravskoslezských Beskyd a nejlidnatější je obec Mosty u Jablunkova s počtem 3936 obyvatel. Celkově má oblast v tomto okrese 11945 obyvatel, což představuje $6 \%$ z celého okresu a 32\% z chráněné krajinné oblasti. V okrese Nový Jičín se nachází pouze jedna obec, která se do území zařazuje. Má 2332 obyvatel, které představují 2\% z okresu a $6 \%$ z oblasti. Průměrný věk obyvatel 40,9 let dokazuje, že převážná většina obyvatel v oblasti je ekonomickou silou, která se soustředí nejvíce opět v okrese Vsetín. Jedni z nejstarších obyvatel se nacházejí kolem města Jablunkova v obcích Mosty u Jablunkova a Milíkov u Jablunkova. Poměr mezi počtem žen a mužů je zde poměrně rovnoměrný a žádná obec v tomto ohledu nepřevažuje. Počet obyvatelstva se v daném území časem mění. Je to dáno přirozeným přírůstkem, či úbytkem, nebo stěhováním populace. Přirozený i celkový přírůstek dosáhl během roku 2009 záporných hodnot. Vystěhovalí obyvatelé převažují nad přistěhovalými a v malých obcích je to více než zřetelné. Tento fakt poukazuje na to, že je v oblasti stále docela vysoká nezaměstnanost, protože většina území chráněné krajinné oblasti se nachází v Moravskoslezském kraji, a lidé se musí odstěhovávat do větších měst za prací. Pokud se v oblasti nezačne projevovat trend dnešní doby, stěhování z velkých měst na vesnice za klidem venkova, celkový přírůstek se v důsledku umírání starší populace a vysoké nezaměstnanosti bude nadále snižovat $[37,38]$. 


\subsection{Dopravní infrastruktura}

Dopravní infrastruktura patří v každém ohledu k významným parametrům pro případný rozvoj oblasti. V oblasti Moravskoslezských Beskyd je nekvalitní a zejména stav silniční sítě a napojení celého kraje na českou mezinárodní dálniční sít’ je slabé. Infrastrukturu v oblasti zajišt'ují především silnice 1 . třídy a stav okolních silnic v kraji typu 1. - 3. třídy také není dostatečně kvalitní, což samozřejmě znesnadňuje dostupnost oblasti. V současné době je ve výstavbě úsek dálnice D1 z Bohumína do Bílovce, který by měl zajistit napojení na důležité dopravní tepny.

Oproti silniční dopravě poskytuje železniční sít' obstojné spojení jak s Českou republikou, tak i se zahraničím. Velká část tratí se modernizuje a tím se také zlepšuje dostupnost celé oblasti.

Nejbližším spojením s leteckou sítí je Letiště Leoše Janáčka v Ostravě-Mošnově, které poskytuje spojení s Prahou, Vídní, Mnichovem či Splitem. V roce 2007 byla otevřená nová odletová hala.

\section{Využití atraktivit v Moravskoslezských Beskydech pro venkovský cestovní ruch}

$\mathrm{Na}$ základě výčtu informací v předchozích kapitolách je jasné, že tato oblast má velké množství atraktivit, at' už se jedná o přírodní nebo kulturní památky. Ve čtvrté kapitole jsou uvedeny konkrétní návrhy, jak využít oblast z hlediska přírodního i kulturního programu a tím nabídnout zákazníkům větší možnost tvorby aktivit pro volný čas. Návrhy jsou zpracovány na obecné rovině tak, aby je bylo možné využít pro tvorbu doprovodných programů a obohatit $\mathrm{s}$ nimi nabídku vybraných zařízení v kapitole 3.1. Zařízení pak dané lokality mohou využít ve své vlastní propagaci a tak zvýšit svoji konkurenceschopnost v regionu a tím podpořit rozvoj venkovského cestovního ruchu.

Jak je uvedeno v kapitole 3.2. v oblasti Moravskoslezských Beskyd je nespočet přírodních atraktivit, proto je zde velký potenciál pro rozvoj turistiky, pěší turistiky, cykloturistiky, a hipoturistiky.

\subsection{Turistika}

Jak je uvedeno v kapitole 3.2. v oblasti Moravskoslezských Beskyd je nespočet přírodních atraktivit, proto je zde velký potenciál pro rozvoj turistiky. Turistika je pro oblast Moravskoslezských Beskyd naprosto zásadní a podstatné odvětví. Oblast je protkána mnohými turistickými trasami. V Beskydech je vyznačeno několik desítek naučných stezek spojených např́k lad s význačnými osobnostmi jako Leoš Janáček, Jan Karafiát, T.G.Masaryk nebo František Palacký. Jedinečnou stezkou je Naučná stezka Mionší, která vede v Dolní Lomné okrajovými partiemi tzv. pralesa Mionší. Další naučné stezky vedou za přírodními zajímavostmi Beskyd jako například Čertův mlýn, Jahodná, Palkovické hůrky. Po stopách pohanského boha Radegasta vás provede stejnojmenná stezka, která vám odkryje tajemství místa jeho sídla. K novým stezkám patří NS Prameny řeky Morávky, která vás zavede $\mathrm{k}$ prameni jedné nejznámějších beskydských řek, naučná stezka Lysá hora, s kterou vystoupáte až na vrchol nejvyšší hory Beskyd a obnovená a prodloužená NS Radegast a NS Čertův mlýn [35].

\subsection{Pěší turistika}

Zde lze zařadit formy cestovního ruchu jako lesní turistika a turistika zážitková. Oba trendy samozřejmě přináší pozitiva i negativa. Pozitivem u zážitkového cestovního ruchu je vyhledávání a prožívání sociálních kontaktů a kontaktů s př́írodou a kulturním prostředím. V oblasti se nachází dostatek peších tras, at’ už to jsou naučné stezky, náročnější výšlapy, 
nebo prosté procházky po krásách prrírody. Jednou z nejvýznamnějších tras Moravskoslezských Beskyd je v pralese Mionší, kde se nachází okružní naučná stezka, která je sezonní a vyhrazena pouze pro pěší turistiku. K dalším neméně důležitým a velice atraktivním trasám patří např́íklad trasa Pustevny-Radhošt', za sochou boha Radegasta; výšlap na Lysou horu, Naučná stezka Gruň - Bílý Kříž, Naučná stezka Prameny řeky Morávky a výšlap na Javorový vrch nebo Ostrý.

\subsection{Cykloturistika}

V oblasti je velké množství cyklotras od II. až po IV. třídu. Mnoho z nich má speciální značení s evidenčním číslem cyklotrasy a kilometráží. Na kolech je možné projezdit trasy jako okruh kolem Žermanické přehrady o délce $46 \mathrm{~km}$; Beskydský okruh s délkou $24 \mathrm{~km}$; z Pusteven přes Martiňák, Čeladnou do Ráztoky, délka 29 km; Z Bílé na Kozí hřbety a zpět, délka $18 \mathrm{~km}$. Všechny trasy samozřejmě nabízejí plno zajímavých zastávek během cesty, kde můžeme využít jak nejrůznější prohlídky kulturních nebo přírodních památek, tak také posezení v některých chatách, restauracích nebo penzionech. K dispozici jsou také půjčovny kol [36].

\subsection{Hipoturistika}

Hipoturistika bývá součást doprovodných programů venkovské turistiky a také specifickou formou agroturistiky. V oblasti se nachází jak malé ranče, tak i velké jízdárny. Sportovní klub Skalický Dvůr ve Frýdku-Místku je jízdárna se zaměřením na rekreační ježdění a je umístěna na statku v krásné přírodě na úpatí Beskyd. V menším měřítku dá čas strávený na koních nalézt v Pensionu Jízdárna, Morávka. Problém u hipoturistiky je dán faktem, že ne vždy tyto nařízení fungují v souladu se zásadami venkovského cestovního ruchu, lze však s konkrétními jízdárnami navázat spolupráci a využít jen možnost ježdění na koni pro své zákazníky.

\subsection{Zimní aktivity}

Zimní sporty ve venkovském cestovním ruchu nemají přímo zastoupení, vzhledem k tomu, že je blízce svázán se zemědělskými činnostmi na farmě. Zákazníkům lze nabídnou v zimě ubytování na farmě a současně možnost moderního lyžování. Toto může sloužit k jako dobrý způsob, jak překlenout mezisezónní období. Přehled nejvýznamnějších středisek je uveden v kapitole 3.4.

\subsection{Kulturní akce}

Jak je uvedeno v kapitole 3.3. tato oblast nabízí velkou škálu kulturních aktivit. Provozovatelé farem, pak mají možnost pro své klienty realizovat zájezdy na tyto akce a tak plně využít potenciál dané oblasti.

Na základě uvedených informací je zřejmé, že provozovatelé vybraných zařízení mají velké možnosti, jak obohatit svou nabídku. Mezi slabé stránky regionu můžeme považovat celkovou negativní image regionu, jako důsledek dojmu velmi silné průmyslové aglomerace, kraj má pověst oblasti s velmi znečištěným životním prostředím, je zde vysoká nezaměstnanost. Další negativní aspekty pak mohou být nedostatek kapitálu v zemědělství, zde se právě nabízí možnost využití venkovského cestovního ruchu, nízká konkurenceschopnost venkovské ekonomiky, vylidňování venkova a stále nízké využití zemědělské produkce pro nepotravinářské účely. 


\section{Závěr}

Cílem příspěvku bylo určit, které přírodní, kulturní a sportovní atraktivity Moravskoslezských Beskyd lze využít jako podporu rozvoje venkovského cestovního ruchu. Z uvedeného vyplývá, že CHKO Moravskoslezské Beskydy má velký potenciál, který je dán hlavně přírodou a všudypřítomnými lokalitami se statusem prrírodních rezervací, národních přírodních rezervací a památek. Je zde také bohaté zázemí historicko - kulturních památek. Významné možnosti rovněž nabízí blízkost četných hraničních přechodů s Polskem a Slovenskem, a tím snadný přístup návštěvníků ze sousedních zemí. Značná část regionu je tvořena zalesněnými plochami, což je předpoklad pro úspěšné provozování zelených forem cestovního ruchu. Oblast nabízí celoroční využití. Je zde velké množství lyžařských areálů, běžeckých tratí v zimních měsících a zařízení pro relax a wellness.

Mezi jisté nedostatky této oblasti pak patř́ špatná dopravní dostupnost některých turistických atraktivit a nekvalitní silniční značení, s tím související špatná kvalita místních komunikací a nedostatek parkovacích míst. Ač blízkost hranic s Polskem nebo Slovenskem vyloženě vybízí zahraniční návštěvníky k návštěvě, je zde návštěvnost zahraničních turistů relativně nízká.

Oblast nabízí široký potenciál dalšího rozvoje. Nabízí se modernizace lyžařských středisek, zaměření se na zahraniční klientelu, větší propagace a hlavně využití nových forem cestovního ruchu, jako je právě venkovský cestovní ruch. Je zde třeba také poukázat na využití udržitelného rozvoje k podpoře konkurenceschopnosti a snažit se o další rozvoj turisticky atraktivních lokalit a čerpání národních a mezinárodních podpůrných programů, dotací.

Mezi přetrvávající problémy patří neustále se zhoršující kvalita silnic, neúčinná marketingová strategie a jistá stagnace zlepšování kvality služeb v zařízeních určených pro cestovní ruch.

Provozovatel farmy může pro své zákazníky realizovat široký program právě na základě uvedených atraktivit v oblasti Moravskoslezských Beskyd.

\section{Literatura:}

[1] BERÁNEK, J., KOTEK, P. Řizení hotelového provozu. Praha: Grada Publishing, 1996.

[2] BURIAN, M. První prìvodce venkovskou turistikou aneb Jedou k nám hosté. Brno: ECEAT, 1999.

[3] JAKUBÍKOVÁ, D., Marketing v cestovním ruchu. Praha: Grada, 2009, ISBN 978-80247-3247-3.

[4] JANOTKA, K. Venkovská turistika a agroturistika. Pardubice: SOŠ CR, 1999.

[5] KOSTKOVÁ, M., Udržitelný rozvoj venkova a cestovní ruch. Chrudim: Vodní zdroje Ekomonitor spol. s.r.o., 2010, ISBN 978-80-86832-52-4.

[6] KOTLER, P.et al. Moderní marketing. Praha: Grada Publishing, 2007, 978-80-2471545-2.

[7] NĚMČANSKÝ, M. Agroturistika. Karviná: SU OPF, 1996, ISBN 80-85879-36-0.

[8] PASKOVÁ, M., ZELENKA, J. Výkladový slovník cestovního ruchu. Praha: Ministerstvo pro místní rozvoj, 2002, ISBN 80-239-015-24.

[9] POUROVÁ, M. Agroturistika. Praha: PEF ČZU, 2002, ISBN 80-213-0965-2.

[10] POLIAČIKOVÁ, E. Marketing I. Banská Bystrica: Ekonomická fakulta UMB, 2007, ISBN 978-80-8083-363-3.

[11] VAŠTÍKOVÁ, M. Marketing služeb efektivně a moderně. Praha: Grada Publishing, 2008.

[12] ZELENKA, J. Trvale udržitelný rozvoj. České Budějovice: Životní prostředí, 1999, ISSN 0044-4863. 


\section{Elektronické zdroje:}

[13] Chráněná krajinná oblast Beskydy, 2011. Chráněná krajinná oblast Beskydy. [online]. [cit. 2011-01-25]. Dostupné z http://nature.hyperlink.cz/Beskydy/

[14] Ubytování, 2011, Beskydy.cz.[online]. [cit. 2012-05-17]. Dostupné $\mathrm{z}$ http://www.beskydy.cz/Content/default.aspx

[15] Najdi ubytování nebo zážitek, 2011, Prázdniny na venkově. [online]. [cit. 2011-02-15]. Dostupné z http://www.prazdninynavenkove.cz/search/subjekty/?druh_ubytovani=\&typ_zarizeni= \&zvirata=\&region=13\&jmeno

[16] Beskydy, zpravodaj chráněné krajinné oblasti, 2007, Beskydy, ochrana přírody. [online]. [cit. 2011-02-10]. Dostupné z

http://www.beskydy.ochranaprirody.cz/wps/wcm/connect/76bf988045a17d2397bd9f50 dce55dd5/zpravodaj-1-07web.pdf?MOD=AJPERES\&CACHEID=76bf988045a17d2397bd9f50dce55dd5

[17] Beskydy, zpravodaj chráněné krajinné oblasti, 2003, Beskydy, ochrana př́rody. [online]. [cit. 2011-01-11]. Dostupné z

http://www.beskydy.ochranaprirody.cz/wps/wcm/connect/3e1bb60045a1679b92a99b50 dce55dd5/zpravodaj-1-03web.pdf?MOD=AJPERES\&CACHEID=3e1bb60045a1679b92a99b50dce55dd5

[18] Beskydy - Valašsko, 2011. 38 Beskydy -Valašsko. [online]. [cit. 2011-03-17]. Dostupné z http://beskydy-valassko.cz/encyklopedie/objekty1.phtml?id=113727

[19] NPR Mionši, 2011, Chráněná krajinná oblast Beskydy. [online]. [cit. 2011-03-17]. Dostupné z http://nature.hyperlink.cz/Beskydy/Mionsi.htm

[20] PR Travný, 2011, Chráněná krajinná oblast Beskydy. [online]. [cit. 2011-03-17]. Dostupné z http://nature.hyperlink.cz/Beskydy/Travny.htm

[21] PP Vodopády Slatiny, 2011, Chráněná krajinná oblast Beskydy. [online]. [cit. 2011-0317]. Dostupné z http://nature.hyperlink.cz/Beskydy/Vodopady_Satiny.htm

[22] PP pod Lukšincem v Malenovicích, 2011, Beskydy.cz. [online]. [cit. 2011-03-17]. Dostupné z http://zajimavosti.beskydy.cz/content/beskydy-prirodni-zajimavostichranena-uzemi-pp-pod-luksincem-v-malenovicich.aspx

[23] PP Ondrášovy díry, 2011, Chráněná krajinná oblast Beskydy. [online]. [cit. 2011-0311]. Dostupné z http://nature.hyperlink.cz/Beskydy/Ondrasovy_diry.htm

[24] NPR Mazák, 2011, Chráněná krajinná oblast Beskydy. [online]. [cit. 2011-02-20]. Dostupné z http://nature.hyperlink.cz/Beskydy/Mazak.htm

[25] PP Bučací potok, 2011, Beskydy.cz. [online]. [cit. 2011-03-17]. Dostupné z http://zajimavosti.beskydy.cz/content/beskydy-prirodni-zajimavosti-chranena-uzemi-ppbucaci-potok.aspx

[26] Smrk, 2011, Beskydy.cz. [online]. [cit. 2011-03-17]. Dostupné z http://www.beskydy.cz/Content/clanek.aspx?clanekid=18058\&lid=1

[27] Kněhyně, 2011, Turistika.cz [online]. [cit. 2011-05-17]. Dostupné z http://www.turistika.cz/mista/knehyne

[28] PP Kněhyňská jeskyně, 2011, Chráněná krajinná oblast Beskydy. [online]. [cit. 201205-17]. Dostupné z http://nature.hyperlink.cz/Beskydy/Knehynska_jeskyne.htm

[29] Magická hora Radhošt', 2011, Pustevny.cz. [online]. [cit. 2011-03-17]. Dostupné z http://www.pustevny.cz/radhost.htm

[30] Zubří, 2011, Turistika.cz. [online]. [cit. 2011-03-17]. Dostupné z http://www.turistika.cz/mista/zubri

[31] NPR Salajka, 2011, Chráněná krajinná oblast Beskydy. [online]. [cit. 2011-03-17]. Dostupné z nature.hyperlink.cz/Beskydy/Salajka.htm 
[32] O Lysé hoře, 2011, Lysá hora - královna Moravskoslezských Beskyd. [online]. [cit. 2011-02-05]. Dostupné z http://www.lysahora.cz/tema/tema.phtml?id=6344

[33] Beskydy - lidová kultura, 2011, beskydy.cz. [online]. [cit. 2011-03-17]. Dostupné z http://informace.beskydy.cz/content/beskydy-informacni-texty-beskydy-lidovakultura.aspx

[34] Beskydy - poznávání, 2011, beskydy.cz. [online]. [cit. 2012-05-03]. Dostupné z http://kultura.beskydy.cz/Content/clanek_list.aspx?lid=1\&nav=1\&abstraktid=25\&tctr1=3

[35] Turistika, naučné trasy, vrcholy, hory, 2011, Beskydy.cz. [online]. [cit. 2012-05-17]. Dostupné z http://turistika.beskydy.cz/Content/clanek_temata.aspx?clanekid=18030\&abstraktid=32; $8991 ; 10086$

[36] Cyklotrasy Beskydy, Javorníky, Ostravsko, Zlínsko, 2011, Cyklistika Krnov. [online]. [cit. 2012-05-17]. Dostupné z http://www.cyklistikakrnov.com/Cyklotrasy/CyklotrasyBeskydy.htm

[37] Český statistický úruad, 2011, Krajská správa ČSU v Ostravě. [online]. [cit. 2011-01-10]. Dostupné z http://www.czso.cz/xt/redakce.nsf/i/home/.

[38] Ministerstvo práce a sociálních věcí, 2011. [online]. [cit. 2011-01-10]. Dostupné z http://www.mpsv.cz/cs/10/

\section{JEL L83}

\section{Mgr. Václavínková Klára}

Odborný asistent katedry cestovního ruchu

Slezská univerzita v Opavě, Obchodně podnikatelská fakulta v Karviné Univerzitní nám. 1934/3, 73340 Karviná

vaclavinkova@opf.slu.cz 